\title{
An Evaluation Constructivist Approach in High School Teaching Process: A Scale Development and Validation
}

\begin{abstract}
By Dolgun Aslan ${ }^{*}$, Seyfettin Arslan ${ }^{\dagger} \&$ Hasan Aydin ${ }^{ \pm}$
The purpose of this study was to evaluate the educational process of students in terms of fundamental principles and approaches based on the constructivist approach in Turkey. In this study, which was carried out using quantitative methods, the internal consistency coefficient of the scale developed was estimated to be high. Cronbach's alpha values ranged between $\alpha=.86$ (teaching process), and $\alpha=.69$ (gains), and the alpha value for the total scale was calculated as $\alpha=.75$. The population of the research comprised students continuing their education in three public and three private science high schools in Istanbul. The initial number of items in the student scale was 25 . As a result of the pilot test, the student scale was reduced to 19 Items. In the exploratory factor analysis of the scale used in this study 5 factors emerged.
\end{abstract}

Keywords: constructivist, educational process, evaluation, high school, science, scale development.

\section{Introduction}

Although Turkey has used the constructivist approach in the development of its curriculum since 2005, the last place finish among 34-member countries of Organization for Economic Cooperation and Development (OECD) in the field of education shows that Turkey is facing a severe problem. Many studies have found that the Turkish Education System still faces acute issues in terms of its curricula and the desired results for education have not been achieved (Aslan \& Aydin, 2013). Güneş and Baki (2011) used the case study method and suggested that many factors prevented achieving the desired results in the teaching-learning process. In their research, they stated that a lack of infrastructure, crowded classrooms, and the inadequacy of teaching hours prevented the utilization of the teaching process according to the constructivist approach principles.

Therefore, today, the Turkish Education System needs to solve the problems related to the implementation of the constructivist approach forming the basis of the current teaching processes. To do so, a determination of why the desired gains cannot be achieved and which factors prevent their achievement is required.

Turkey has been interested in the changes and developments observed at the global level, and the educational structure is being restructured in the light of these and shortcomings are being determined, and attempts are being made to correct

\footnotetext{
*Independent Researcher, Turkey.

†Independent Researcher, Germany.

${ }^{ \pm}$Associate Professor of Multicultural Education, Florida Gulf Coast University, USA.
} 
them. The changes observed in Turkey's population structure, family characteristics, social structure, consumption methods, and political, social, scientific and technological structure have forced the structure of the education system to change, as well. As a result, drastic changes in the educational system and the need for Turkey to align with global developments are necessary (MOE, 2005). Thus, the new Turkish curriculum has been tried to meet these needs. At this point, educational philosophies, teaching theories, contemporary teaching principles, common targeted skills, and intermediary disciplines that are considered necessary have been utilized.

The purpose of this paper is to investigate Turkish education system, to determine the attitudes towards the constructivist approach in the context of the data, to examine the teaching process based on the constructivist approach according to the emerging learning products, to reveal how the science high school curriculum is evaluated in line with the views of students, to determine the deficiencies and mistakes in the teaching process, and to contribute to the formation of a better teaching-and-learning process.

\section{Literature Review}

Sönmez (2008) emphasized that the constructivist approach stemmed from Dewey's philosophical understanding and educational views, Piaget and Vygotsky's views on human biological characteristics, cultural structures, social context and linguistic development, and Bruner and Aulowerel's ideas about learning. Dewey (1939) rejected the invariance and objectivity of knowledge and stated that undertaking research and investigation was necessary. $\mathrm{He}$ also dismissed the role-learning based education system and noted that education should be seen as life itself, not as preparation for life. Dewey expressed critical opinions in determining the basic principles of constructivism (Colburn, 2000; Hall \& Quinn, 2014; Mahoney, 2004).

The constructivist approach accepts aspects of learning (rather than its being taught), learner autonomy, experiences in learning, primary sources of information, the necessity of the fact that knowledge should be seen as a process of meaning formation and the fact that knowledge does not depend on objective reality (Aydin, 2014; Driscoll, 2000). In addition, this learning theory is based on supporting the natural curiosity of humans and a consideration of how learning is done, that the context is a determinant in learning and that the participation of the students under teacher guidance is meaningful (Glasersfeld, 1989; Huang, Rauch, \& Liaw, 2010; Piaget, 1964; Vygotsky, 1997). In light of these considerations, the constructivist approach considers individual experiences, context, subjective values, and facilitator role of teachers is vital.

Similarly, Kaptan and Korkmaz (2001) emphasized that learning should be seen as a process in which experimental, subjective, and individual efforts are carried out. In terms of constructivism, Fer and Cirik (2007) said that, in general, learning theory explains how an individual structures information in his/her learning process, what activities are performed in this structuring process and what 
factors affect this structuring process. As Akınoğlu (2003) stated, knowledge is internalized by an individual's attribution of meaning to knowledge in a unique way based on his/her experiences, observations, and logical analyzes. Parallel to these opinions regarding the position and role of the student in the learning process, Asan and Güneş (2000) argued that students should be given opportunities to participate in activities, to ask questions about a problem and to achieve the results by utilizing student-centred activities.

Thanasoulas (2002) emphasized that, in constructivism, students carry out and acquire new learning by combining new acquisitions with what they hear, read, and see based on individual experiences. According to Woofter (2019), and Halpern (2017) students should be allowed to reveal their potential by enabling them to bear the responsibility of learning through concrete experiences and should be encouraged at the point of self-control. In addition, Açıkgöz (2009) stated that teachers should have positive and real expectations of students. Because the characteristics of students greatly influence the expectations of teachers, teachers should provide the opportunity for the development of student selfconfidence and belief in success. The constructivist approach seeks to offer approaches that will provide opportunities for students to meet expectations, to be motivated, and to increase their interest in internal dimensions will play a critical role in achieving educational goals and creating an efficient process (Aslan \& Aydin, 2015; 2016; Lapaglia, 2018).

This study was designed to develop a scale to evaluate the teaching process in science high schools in terms of the basic principles and values of the constructivist approach. Answers for the following questions were sought to achieve this objective.

1. What are the results of the exploratory factor analysis of the Scale for Evaluation of Teaching Process in Science High Schools in terms of the constructivist approach?

2. What are the results of the reliability test for the Scale for Evaluation of Teaching Process in Science High Schools in terms of constructivist approach?

3. What are the common load values of all items in the Scale for Evaluation of Teaching Process in Science High Schools in terms of the constructivist approach?

\section{Method}

This study used a quantitative method. According to Yıldırım and Şimşek (2008), reality is based on objective data in quantitative research. The main objective in the quantitative process is to provide an opportunity to present results with quantitative data through the measurement of variables and correlations.

The objective of this current study was to evaluate the teaching-learning process in science high schools in terms of constructivist approach with a 5-point Likert-type scale for statements that the researcher prepared. A scale comprising 
25 statements was developed to determine the opinions of students. In this process, faculty members who were experts in their fields were asked to examine the items mentioned in the scale to determine if they were in accordance with the underlying philosophy and logic of the constructivist approach and whether students could easily understand them considering the readiness and perception levels of the target audience. After this review, the necessary changes were made.

After the necessary permission was received from the Directorate of National Education, a pilot study was conducted among 255 students in public and private science high schools in Istanbul in the fall semester of 2014-2015. The 5-point Likert type utilized had possible responses ranging from Strongly Disagree (1), Disagree (2), Partially Agree (3), Agree (4), to Strongly Agree (5). An exploratory factor analysis was conducted to the factor structure of the scale, which resulted in 5 factors in the student survey after the pilot study was conducted.

\section{Participants and Sampling}

The sample for this study was selected from three public science high schools (F1, F2, F3) and three private science high schools (ÖF1, ÖF2, ÖF3) and a questionnaire was designed for the students in these high schools. Within the scope of this research, "A Scale for Determining the Views of Science High School Students on Constructivist Approach" was prepared for quantitative research and applied to the selected public and private science high schools in Istanbul. Necessary appointments were made from the science high schools and receipts of permission were presented to the school administrators. In this study, sampling was conducted through Simple Random Sampling. Büyüköztürk (2012) explained that the simple random sampling method was the random selection of sampling units of the population to be examined regardless of any preconditions. The population of this research comprised students in the selected public and private science high schools operating under the Turkish National Education system. The sample of the pilot study included students in the public and private science high schools in Istanbul province, and the response rate was $87 \%$.

The frequency and percentage values of the student dimension related to the pilot scheme are given in Table 1 and Table 2.

Table 1. Frequency and Percentage Values for Gender

\begin{tabular}{|l|c|c|c|}
\hline Group & f & Valid \% & Cum. \% \\
\hline Female & 51 & 20 & 20 \\
\hline Male & 204 & 80 & 100 \\
\hline Total & 255 & 100 & \\
\hline
\end{tabular}

As seen in Table 1, $51(20 \%)$ of the students in the sample group were female, and $204(80 \%)$ were male. 
Table 2. Frequency and Percentage Values for Grade Level

\begin{tabular}{|l|c|c|c|}
\hline Group & f & Valid \% & Cum. \% \\
\hline $10^{\text {th }}$ Grade & 105 & 41.18 & 41,18 \\
\hline $11^{\text {th }}$ Grade & 84 & 32.94 & 74,12 \\
\hline $12^{\text {th }}$ Grade & 66 & 25.88 & 100 \\
\hline Total & 255 & 100 & \\
\hline
\end{tabular}

As can be seen in Table 2, 105 (41.18\%) of the students in the sample group were $10^{\text {th }}$ graders; $84(32.94 \%)$ were $11^{\text {th }}$ graders; and $66(25.88 \%)$ were $12^{\text {th }}$ graders. Because the pilot project was carried out in October of 2015 9th graders were not included because they could not fully comprehend the scale for the teaching process because they were new to their schools.

\section{Data Collection Tools}

In this study, data were obtained through a questionnaire. According to Aydin (2019), a measurement tool is valid only to the extent to which it can measure what it is intended to measure. Thus, a measurement tool should be on a single question basis and in a structure suitable for it as a whole. To achieve the objective of this study, a literature search about constructivist teaching theory was performed, and similar searches were conducted in the context of problems and sub-problems. Also, the opinions of three experts in the field of constructivist learning theory and educational programs and teaching were sought. Additionally, seven people who were continuing their doctoral studies in the field of educational sciences were asked to evaluate the scale.

The scale for determining the opinions of science high school students about the constructivist approach was prepared with a 5-Likert type scale and utilized the categories Strongly disagree (1), Disagree (2), Partially agree (3), Agree (4), Strongly agree (5). To assess the validity and reliability of the scale, 25 items related to the student dimension were determined during the pilot scheme process and then applied. After the pilot scheme, item elimination was carried out during factor analysis, and the number of items on the student scale was reduced to 19 .

\section{Data Analysis and Results}

Cronbach's alpha values for the total consistency and the internal consistency calculated on the items contained in each sub-dimension are given below.

Table 3. Sub-dimensions Determined as a Result of Factor Analysis and Reliability Coefficients of These Dimensions

\begin{tabular}{|l|c|}
\hline Factor & Cronbach's alpha \\
\hline Teacher approaches & .821 \\
\hline Teaching process & .860 \\
\hline Measurement and evaluation & .779 \\
\hline Gains & .691 \\
\hline Content and teaching materials & .701 \\
\hline Total & .753 \\
\hline
\end{tabular}


As can be seen from the data in Table 3, the internal consistency coefficients of the scale except for one factor were found to be high. The Cronbach's alpha values ranged from $\alpha=.86$ (teaching process) to $\alpha=.69$ (gains). Alpha value was calculated as $\alpha=.75$ for the total scale. These values indicate that the internal consistency of the scale is extremely high. Because the internal consistency coefficient for the total of the scale was higher than .70, the boundary value in the sub-dimension of gains was not considered.

This section contains the results obtained from the analysis of the data that were collected in the research with a 5-point Likert scale.

Table 4. The Results of Kaiser-Meyer-Olkin (KMO) Measure of Sampling Adequacy and Bartlett's Test of Sphericity

\begin{tabular}{|l|c|c|}
\hline \multicolumn{2}{|c|}{ Kaiser-Meyer-Olkin (KMO) Measure of Sampling Adequacy } & .832 \\
\hline \multirow{3}{*}{ Bartlett's Test of Sphericity } & Chi-Square Value & 2764.977 \\
\cline { 2 - 3 } & S. Degree & 171 \\
\cline { 2 - 3 } & $\mathrm{p}$ & .000 \\
\hline
\end{tabular}

Table 4 shows that the KMO value was, 832, and the Bartlett value was significant $(\mathrm{x} 2=2764.98 ; \mathrm{p}<.001)$ after item elimination. Büyüköztürk (2012) stated that KMO a value being higher than 50 and Bartlett value being significant confirmed the eligibility of the data for factor analysis. In this context, the sample size and structure were factorable, and the procedures were continued. For this purpose, the results obtained by calculating the common load values obtained by Principal Component Analysis are given in Table 5.

Table 5. Common Load Values

\begin{tabular}{|l|c|}
\hline Item & Extraction \\
\hline $\begin{array}{l}\text { Q2. The gains provide us to improve ourselves in many aspects (cognitive, } \\
\text { affective, psychomotor). }\end{array}$ & .529 \\
\hline $\begin{array}{l}\text { Q3. The activities carried out during the teaching process are able to allow us } \\
\text { to comprehend and apply the information rather than memorizing it. }\end{array}$ & .693 \\
\hline $\begin{array}{l}\text { Q4. We are allowed to obtain the knowledge and skills we need in daily life } \\
\text { during the teaching process. }\end{array}$ & .631 \\
\hline $\begin{array}{l}\text { Q5. We are given the opportunity to practice with different teaching methods } \\
\text { and techniques according to the gains. }\end{array}$ & .680 \\
\hline $\begin{array}{l}\text { Q7. Teaching activities are performed in a way that will provide the } \\
\text { development of our problem-solving skills. }\end{array}$ & .672 \\
\hline $\begin{array}{l}\text { Q8. Teaching activities are capable of developing our questioning and critical } \\
\text { thinking skills. }\end{array}$ & .657 \\
\hline $\begin{array}{l}\text { Q9. Topics (books, workbooks, materials...) contain contents that will allow } \\
\text { us to comprehend and practice the information rather than memorization. }\end{array}$ & .628 \\
\hline $\begin{array}{l}\text { Q10. That there are a lot of topics in the content makes our learning more } \\
\text { difficult. }\end{array}$ & .556 \\
\hline $\begin{array}{l}\text { Q12. The most part of a class hour is not being conducted with the teacher's } \\
\text { course presentation, but in a way that allows for our active participation. }\end{array}$ & .650 \\
\hline Q13. There is no time for implementation due to the intensity of topics. & .542 \\
\hline
\end{tabular}


Q14. Courses are being conducted by discussions, question-answers etc. rather than the transfer of information by the teacher.

Q15. The teaching process is carried out through collaborative processes that allow the sharing of knowledge and skills rather than the presentation of information by the teacher.

Q16. We are given enough opportunities to turn the theoretical knowledge we have gained during the teaching process into practice.

Q19. Teacher gives us the opportunity to discover and comprehend the information with appropriate tips rather than presenting the information as ready.

Q20. The performance and project tasks given in the teaching process do not serve to achieve gains.

Q21. Our performance and efforts in the course are not taken into consideration in the assessment process as much as written and oral exam scores.

Q22. Evaluations are made to measure higher level gains (application, analysis, synthesis, and evaluation) rather than remembering the learned information.

Q24. Since there is no time left for application, homework is given for the activities.

Q25. There are not enough performance-based assessments.

As Table 5 shows, the common load values of all items were more than 50 . The lowest load value obtained was calculated as .501 in the $21^{\text {st }}$ item. Due to the high values, factor analysis was continued at this stage without an item elimination, and the findings of the explained variance amounts and factor numbers are presented in Table 6 .

Table 6. Explained Total Variance Amounts

\begin{tabular}{|l|c|c|c|c|c|c|c|c|c|}
\hline \multirow{2}{*}{ Factor } & \multicolumn{3}{|c|}{ Initial Eigenvalues } & \multicolumn{3}{c|}{ Total Factor Loads } & \multicolumn{3}{c|}{$\begin{array}{c}\text { Totals of Rotated Factor } \\
\text { Loads }\end{array}$} \\
\cline { 2 - 11 } & Tot. & Vari.\% & Cum. \% & Tot. & Vari.\% & Cum.\% & Tot. & Vari.\% & Cum. \% \\
\hline 1 & 6.936 & 36.508 & 36.508 & 6.936 & 36.508 & 36.508 & 3.201 & 16.846 & 16.846 \\
\hline 2 & 1.801 & 9.480 & 45.988 & 1.801 & 9.480 & 45,988 & 2.890 & 15.208 & 32.054 \\
\hline 3 & 1.375 & 7.236 & 53.224 & 1.375 & 7.236 & 53.224 & 2.422 & 12.749 & 44.803 \\
\hline 4 & 1.262 & 6.644 & 59.867 & 1.262 & 6.644 & 59.867 & 2.203 & 11.597 & 56.400 \\
\hline 5 & 1.050 & 5.527 & 65.394 & 1.050 & 5.527 & 65.394 & 1.709 & 8.994 & 65.394 \\
\hline 6 & .928 & 4.883 & 70.277 & & & & & & \\
\hline 7 & .804 & 4.230 & 74.507 & & & & & & \\
\hline 8 & .713 & 3.753 & 78.260 & & & & & & \\
\hline 9 & .667 & 3.510 & 81.770 & & & & & & \\
\hline 10 & .574 & 3.023 & 84.793 & & & & & & \\
\hline 11 & .554 & 2.915 & 87.708 & & & & & & \\
\hline 12 & .493 & 2.593 & 90.301 & & & & & & \\
\hline 13 & .413 & 2.172 & 92.473 & & & & & & \\
\hline 14 & .391 & 2.057 & 94.530 & & & & & & \\
\hline 15 & .337 & 1.773 & 96.303 & & & & & & \\
\hline 16 & .300 & 1.580 & 97.883 & & & & & & \\
\hline 17 & .220 & 1.159 & 99.043 & & & & & & \\
\hline 18 & .164 & .861 & 99.903 & & & & & & \\
\hline 19 & .018 & .097 & 100.000 & & & & & & \\
\hline
\end{tabular}


Table 7. Rotated Component Matrix after Factor Analysis

\begin{tabular}{|c|c|c|c|c|c|}
\hline \multirow{2}{*}{ Item } & \multicolumn{5}{|c|}{ Component } \\
\hline & 1 & 2 & 3 & 4 & 5 \\
\hline $\begin{array}{l}\text { Q14. Courses are being conducted by discussions, question- } \\
\text { answers, etc. rather than the transfer of information by the } \\
\text { teacher. }\end{array}$ & .842 & & & & \\
\hline $\begin{array}{l}\text { Q15. The teaching process is carried out through } \\
\text { collaborative processes that allow the sharing of knowledge } \\
\text { and skills rather than the presentation of information by the } \\
\text { teacher. }\end{array}$ & .729 & & & & \\
\hline $\begin{array}{l}\text { Q12. The most part of a class hour is not being conducted } \\
\text { with the teacher's course presentation, but in a way that } \\
\text { allows for our active participation. }\end{array}$ & .646 & & & & \\
\hline $\begin{array}{l}\text { Q19. Teacher gives us the opportunity to discover and } \\
\text { comprehend the information with appropriate tips rather } \\
\text { than presenting the information as ready. }\end{array}$ & .604 & & & & \\
\hline $\begin{array}{l}\text { Q4. We are allowed to obtain the knowledge and skills we } \\
\text { need in daily life during the teaching process. }\end{array}$ & & .543 & & & \\
\hline $\begin{array}{l}\text { Q7. Educational activities are carried out in a way that will } \\
\text { allow the development of our problem-solving skills. }\end{array}$ & & .790 & & & \\
\hline $\begin{array}{l}\text { Q8. Educational activities are capable of developing our } \\
\text { questioning and critical thinking skills. }\end{array}$ & & .767 & & & \\
\hline $\begin{array}{l}\text { Q3. The activities carried out during the teaching process } \\
\text { are able to allow us to comprehend and apply the } \\
\text { information rather than memorizing it. }\end{array}$ & & .578 & & & \\
\hline $\begin{array}{l}\text { Q16. We are given enough opportunities to turn the } \\
\text { theoretical knowledge we have gained during the teaching } \\
\text { process into practice. }\end{array}$ & & .565 & & & \\
\hline $\begin{array}{l}\text { Q24. Since there is no time left for application, homework is } \\
\text { given for the activities. }\end{array}$ & & .514 & & & \\
\hline $\begin{array}{l}\text { Q22. Evaluations are made to measure higher level gains } \\
\text { (application, analysis, synthesis, and evaluation) rather than } \\
\text { remembering the learned information. }\end{array}$ & & & .849 & & \\
\hline Q25. There are not enough performance-based assessments. & & & .846 & & \\
\hline $\begin{array}{l}\text { Q21. Our performance and efforts in the course are not } \\
\text { taken into consideration in the assessment process as much } \\
\text { as written and oral exam scores. }\end{array}$ & & & .644 & & \\
\hline $\begin{array}{l}\text { Q20. The performance and project tasks given in the } \\
\text { teaching process do not serve to achieve gains. }\end{array}$ & & & & .800 & \\
\hline $\begin{array}{l}\text { Q5. We are given the opportunity to practice with different } \\
\text { teaching methods and techniques according to the gains. }\end{array}$ & & & & .726 & \\
\hline $\begin{array}{l}\text { Q2. The gains provide us to improve ourselves in many } \\
\text { aspects (cognitive, affective, psychomotor). }\end{array}$ & & & & .529 & \\
\hline $\begin{array}{l}\text { Q9. Topics (books, workbooks, materials...) contain } \\
\text { contents that will allow us to comprehend and practice the } \\
\text { information rather than memorization. }\end{array}$ & & & & & .759 \\
\hline $\begin{array}{l}\text { Q13. There is no time for implementation due to the } \\
\text { intensity of topics. }\end{array}$ & & & & & .690 \\
\hline $\begin{array}{l}\text { Q10. That there are a lot of topics in the content makes our } \\
\text { learning more difficult. }\end{array}$ & & & & & .666 \\
\hline
\end{tabular}


As a result of the factor analysis made with principal components analysis by using an Eigenvalue of 1, the initial scale had a five-factor structure. These five factors explained $65.39 \%$ of the total variance. For the first factor, the Eigenvalue was 6.94 , and its factor loading was $36.51 \%$. The difference between the second factor and the loading was very high (approximately $27.03 \%$ ). The following sections of the analysis were carried out on the multifactor structure, and the results obtained by rotating with varimax vertical rotation technique are presented below to examine the factors into which the items were gathered.

When the varimax vertical rotation technique examined the distribution of the items to the factors, all items had more than a $10 \%$ difference $(<.30)$ for more than one factor. This indicated that all items in the scale had a sufficiently distinctive structure. For that reason, factor analyses were ended without item elimination. Table 8 shows the items, and the number of items in the subdimensions is presented below.

Table 8. Sub-dimensions Determined as a Result of Factor Analysis and Items that took Load Values from these Sub-Dimensions

\begin{tabular}{|l|c|c|}
\hline Factor & Number of Items & Item Number \\
\hline 1 & Teacher approaches & $12,14,15,19$ \\
\hline 2 & Teaching process & $3,4,7,8,16,24$ \\
\hline 3 & Measurement and evaluation & $21,22,25$ \\
\hline 4 & Gains & $2,5,20$ \\
\hline 5 & Content and teaching materials & $9,10,13$ \\
\hline Total & & $\mathbf{1 9}$ \\
\hline
\end{tabular}

Table 8 shows the first factor has 4 items (Item 12, 14, 15, and 19); the second factor has 6 items (Item 3, 4, 7, 8, 16, and 24); the third factor has 3 items (Item 21, 22, and 25); the fourth factor has 3 items (Item 2, 5, and 20) and the fifth factor has 3 items (Item 9, 10, and 13). Items 20, 2, and 25 are opposite items for the factor in which they are included. The entire scale has 19 items.

Each factor was titled after examining the items in the related factor. In this context, the first sub-dimension was titled as the teacher approaches subdimension; the second sub-dimension was titled as the teaching process subdimension; the third sub-dimension was titled as the measurement and evaluation sub-dimension; the fourth sub-dimension was titled as the gains sub-dimension, and the fifth sub-dimension was titled as the content and teaching materials subdimension. The increase in scores in all factors and total is regarded as the increase of the related feature. After this stage, reliability analysis was performed for the factors.

Distinctiveness comprises the points obtained by comparing the points of the individuals in the upper and lower quarters $(27 \%)$ of the test using the independent group t-test. The aim is to reveal whether the answer given to that item differentiates between the lower and upper groups and to prove its distinctive power (Ergin, 1995). An independent samples t-test was used to determine whether a significant difference existed between the arithmetic means of the upper 
(27\%) and lower (27\%) groups that were determined according to factor total points. The results are presented in Table 9.

Table 9. Independent Group T-test Results to Determine the Distinctiveness of Scale Items

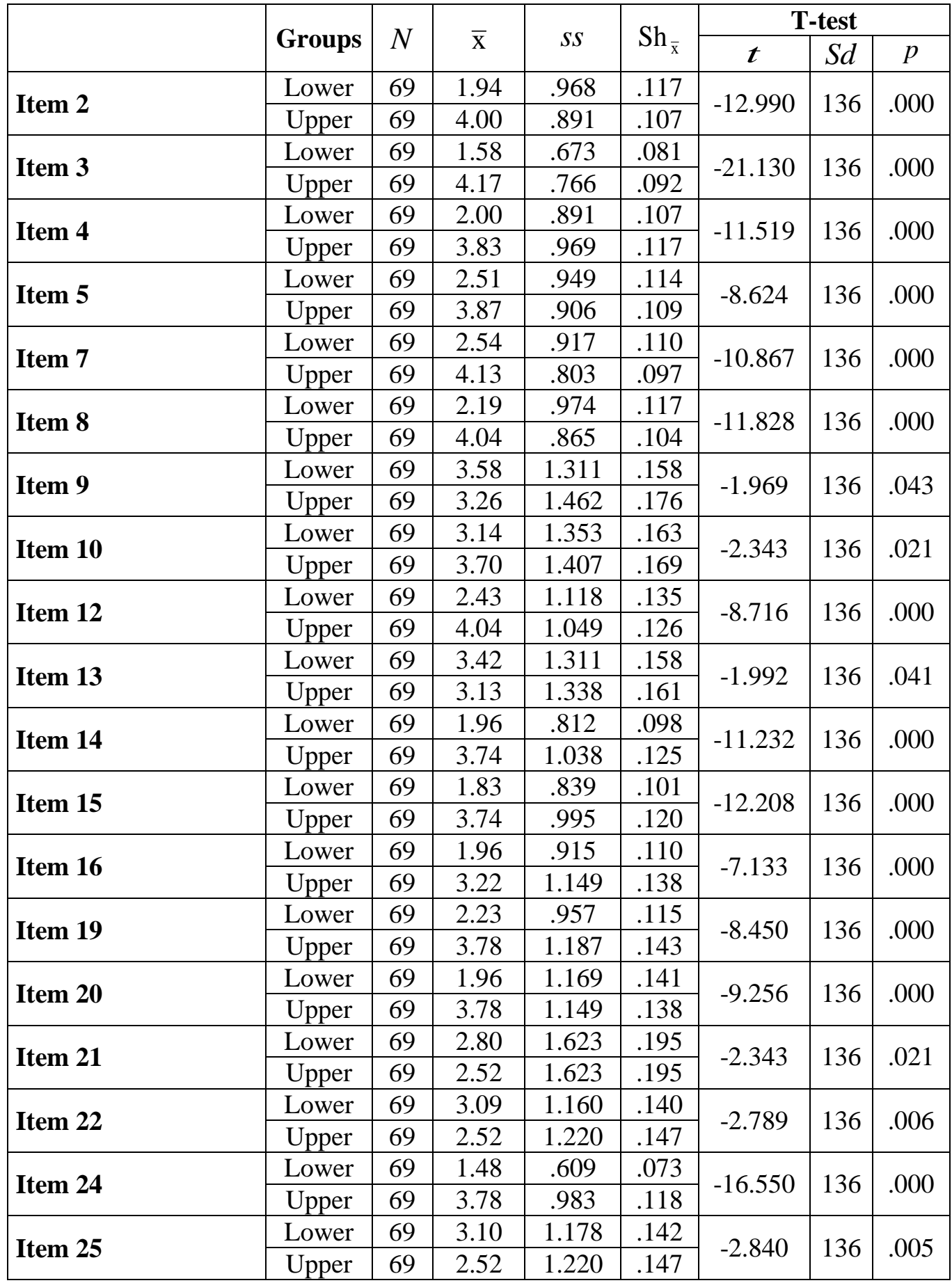

Table 9 shows the results of the independent samples t-test that was performed to determine the distinctiveness of the items and to determine whether a 
significant difference existed between the arithmetic means of the upper (27\%) and lower $(27 \%)$ groups. The differences were found as statistically significant for all groups $(\mathrm{p}<.001)$. These differences were in favor of the upper groups. The obtained results showed that the items of the scale were distinctive. After this result, discriminant analysis was utilized to determine the distinctiveness of the scale sub-dimensions and total points.

Table 10. Independent Group T-test Results to Determine the Distinctiveness of Scale Sub-dimensions and Total Points

\begin{tabular}{|c|c|c|c|c|c|c|c|c|}
\hline \multirow{2}{*}{ Point } & \multirow{2}{*}{ Groups } & \multirow{2}{*}{$N$} & \multirow[b]{2}{*}{$\overline{\mathrm{X}}$} & \multirow[b]{2}{*}{ sS } & \multirow{2}{*}{$\mathrm{Sh}_{\overline{\mathrm{x}}}$} & \multicolumn{3}{|c|}{ T-test } \\
\hline & & & & & & $t$ & $S d$ & $p$ \\
\hline \multirow{2}{*}{ LOWER1 } & Lower & 69 & 8.45 & 2.541 & .306 & \multirow{2}{*}{-14.033} & \multirow{2}{*}{136} & \multirow{2}{*}{.000} \\
\hline & Upper & 69 & 15.30 & 3.164 & .381 & & & \\
\hline \multirow{2}{*}{ LOWER2 } & Lower & 69 & 11.74 & 3.248 & .391 & \multirow{2}{*}{-18.548} & \multirow{2}{*}{136} & \multirow[b]{2}{*}{.000} \\
\hline & Upper & 69 & 23.17 & 3.959 & .477 & & & \\
\hline \multirow{2}{*}{ LOWER3 } & Lower & 69 & 4.74 & 1.080 & .130 & \multirow{2}{*}{-39.324} & \multirow{2}{*}{136} & \multirow{2}{*}{.000} \\
\hline & Upper & 69 & 12.77 & 1.308 & .157 & & & \\
\hline \multirow{2}{*}{ LOWER4 } & Lower & 69 & 6.41 & 2.165 & .261 & \multirow{2}{*}{-14.269} & \multirow{2}{*}{136} & \multirow{2}{*}{.000} \\
\hline & Upper & 69 & 11.65 & 2.155 & .259 & & & \\
\hline \multirow{2}{*}{ LOWER5 } & Lower & 69 & 7.22 & 1.653 & .199 & \multirow{2}{*}{-30.010} & \multirow{2}{*}{136} & \multirow{2}{*}{.000} \\
\hline & Upper & 69 & 13.96 & .865 & .104 & & & \\
\hline \multirow{2}{*}{ TOTAL } & Lower & 69 & 45.72 & 3.568 & .430 & \multirow{2}{*}{-32.454} & \multirow{2}{*}{136} & \multirow{2}{*}{.000} \\
\hline & Upper & 69 & 67.78 & 4.375 & .527 & & & \\
\hline
\end{tabular}

Table 10 shows the results of the independent samples t-test that was performed to determine the distinctiveness of the scale's total point and subdimension points and to determine whether there was a significant difference between the arithmetic means of the upper (27\%) and lower (27\%) groups. The differences were found as statistically significant for all groups $(\mathrm{p}<.001)$. These differences were in favor of the upper groups. The obtained results showed that the items of the scale were distinctive. After this result, a calculation of the correlation of scale items with total points was performed. The results of Item-total and Item-remainder analyses that were performed for this purpose are given in Table 11.

As shown in Table 11, all item correlations were significant in the ItemTotal and Item-Remainder analyses. These significance levels were realized at the $\mathrm{p}<.05$ level for items $9,10,13,21,22$, and 25. and at $\mathrm{p}<.001$ level in others. All these results showed that all items were in the same structure. After these procedures, the interfactor correlations were calculated, and the obtained results are presented below in Table 12. 
Table 11. Correlation Results of Item-Total and Item-Remainder

\begin{tabular}{|l|c|c|c|c|c|}
\hline \multirow{2}{*}{ Item } & \multicolumn{3}{|c|}{ Total Point } & \multicolumn{2}{c|}{ Item-Remainder } \\
\cline { 2 - 6 } & $\mathbf{N}$ & $\mathbf{r}$ & $\mathbf{p}$ & $\mathbf{r}$ & $\mathbf{p}$ \\
\hline S2 & 255 & .618 & .000 & .517 & .000 \\
\hline S3 & 255 & .771 & .000 & .701 & .000 \\
\hline S4 & 255 & .684 & .000 & .608 & .000 \\
\hline S5 & 255 & .514 & .000 & .415 & .000 \\
\hline S7 & 255 & .572 & .000 & .481 & .000 \\
\hline S8 & 255 & .610 & .000 & .517 & .000 \\
\hline S9 & 255 & .166 & .020 & .172 & .020 \\
\hline S10 & 255 & .130 & .035 & .130 & .035 \\
\hline S12 & 255 & .569 & .000 & .470 & .000 \\
\hline S13 & 255 & .136 & .030 & .163 & .030 \\
\hline S14 & 255 & .595 & .000 & .504 & .000 \\
\hline S15 & 255 & .655 & .000 & .572 & .000 \\
\hline S16 & 255 & .537 & .000 & .443 & .000 \\
\hline S19 & 255 & .482 & .000 & .374 & .000 \\
\hline S20 & 255 & -.485 & .000 & -.352 & .000 \\
\hline S21 & 255 & -.136 & .030 & -.206 & .030 \\
\hline S22 & 255 & .126 & 045 & .255 & .045 \\
\hline S24 & 255 & .702 & .000 & .617 & .000 \\
\hline S25 & 255 & -.136 & .030 & -.264 & .030 \\
\hline
\end{tabular}

Table 12. Results of Pearson Product-Moment Correlation Analysis to Determine Interfactor Correlations $(\mathrm{N}=255)$

\begin{tabular}{|c|c|c|c|c|c|c|}
\hline & & LOWER2 & LOWER3 & LOWER4 & LOWER5 & Total \\
\hline \multirow{2}{*}{$\begin{array}{l}\text { Teacher } \\
\text { approaches }\end{array}$} & $\mathrm{r}$ & .659 & .499 & .507 & .284 & .713 \\
\hline & $p$ & .000 & .000 & .000 & .000 & .000 \\
\hline \multirow{2}{*}{ Teaching process } & $\mathrm{r}$ & & .374 & .598 & .304 & .847 \\
\hline & $\mathrm{p}$ & & .000 & .000 & .000 & .000 \\
\hline \multirow{2}{*}{$\begin{array}{l}\text { Measurement and } \\
\text { evaluation }\end{array}$} & $\mathrm{r}$ & & & .395 & .266 & .131 \\
\hline & $p$ & & & .000 & .000 & .044 \\
\hline \multirow{2}{*}{ Gains } & $\mathrm{r}$ & & & & .231 & .687 \\
\hline & $\mathrm{p}$ & & & & .000 & .000 \\
\hline \multirow{2}{*}{$\begin{array}{l}\text { Content and } \\
\text { teaching materials }\end{array}$} & $\mathrm{r}$ & & & & & .137 \\
\hline & $p$ & & & & & .041 \\
\hline
\end{tabular}

Table 12 shows the results of the Pearson Product-Moment Correlation analysis that was conducted to determine whether a significant correlation exists between the factors. As a result, a positive and significant correlation was found between all factors. These results proved that all factors were in the same structure. 


\section{Discussion, Conclusion, and Recommendations}

In this study, the internal consistency coefficients of the student scale were found to be high. Cronbach's alpha for the total of the scale was calculated as $\alpha=.75$. These values indicate that the internal consistency of the scale is at acceptable levels. For the reliability analysis of a scale that is prepared in quantitative studies, if Cronbach's alpha value is more than .70 , then it is considered a good value (Aydin \& Aslan, 2016; Aydin \& Cinkaya, 2018; Kalayc1, 2008; Özdamar, 1999; Ulubey, Aydin, \& Toraman, 2017). For the student survey, the level at which each variable contributed to the main component by considering the principal component analysis, and the common load values of each variable's contributing level to the main component were calculated. The common load values of all items in the scale were found to be more than .50. The lowest load value was calculated as .501 in the $211^{\text {st }}$ item. The fact that the common load values were high in the study shows that item elimination was no longer necessary.

As a result of factor analysis made with principal component analysis by using Eigenvalue as 1, the conclusion was made that the scale had a five-factor structure at the first stage. These results show that the analysis should be continued on a multi-factorial structure. After this step, to examine in which factors the items were gathered, the distribution of the items to the factors was examined by varimax vertical rotation, and all items reached more than $10 \%$ difference $(<.130)$ in more than one factor. This data shows that all items in the scale have distinctive enough structure.

As a result of the research, the first factor had 4 items; the second factor had 6 items; the third factor had 3 items; the fourth factor had 3 items, and the fifth factor had 3 items. These data show us that each factor is related to the items in the scale sufficiently. The number of items in the scale that was initially 25, was reduced 19 in the final stage. The title of each factor was determined after considering the meanings of the items.

In this study, the first factor was labeled "teacher approaches," the second factor "teaching process," third factor "measurement and evaluation," the fourth factor "gains" and the fifth factor "content and teaching materials."

In this pilot scheme, the factors reached in the context of the data were related to the elements in the curriculum. Ornstein and Hunkins (2014) stated that a curriculum consists of aim, content, educational status (teaching process) and test cases. The factors reached in the study in this respect were directly related to the program elements. Items in the scale and the factors reached in the direction of these items were related to the basic principles and approach of constructivist teaching theory. The reached factors and the items they contain included points like the position of the students in the process, whether an active participation opportunity exists, teacher guidance, the appropriateness of the aims for the student level, the reality of the content for the living conditions, the level of the teacher approach, how the evaluation is made, and how much emphasis is put on cooperative learning (Andrews, 2017; Fer \& Cirık, 2007; Toraman, Aydin, \& Ulubey, 2016). 
An independent group t-test was used to determine whether a difference existed between the arithmetic averages of upper (27\%) and lower (27\%) groups determined according to factor total scores. The differences were found statistically significant for all groups and were observed in favor of upper groups. These results showed that the items in the scale were sufficiently distinctive. Also, the correlations of all items were significant in item-total and item-remainder analyses. This indicates that all items of this scale were in the same structure.

The Pearson Product-Moment Correlation analysis found a positive correlation among all factors, and all the factors were in the same structure. These data show that the scale was compatible both on the item and factor basis and was competent to serve the intended purposes. Thus, the conclusion can be made that the scale has construct validity. The feedback obtained based on the assessments of the students who were studying at science high schools may serve an essential function in the elimination of these problems by showing the deficiencies and mistakes related to the educational issues. The hope is that this scale will lead to other research.

\section{References}

Açıkgöz, K.Ü. (2003). Aktif Öğrenme [Active Learning]. İzmir: Eğitim Dünyası Yayınları. World of Education Publications.

Açıkgöz, K.Ü. (2009). Etkili Öğrenme ve Öğretme (8. Bask1) [Effective Learning and Teaching $\left(8^{\text {th }}\right.$ ed.) ]. İzmir: Biliş.

Akınoğlu, O. (2004). Yapılandırmacı Öğrenme ve Coğrafya Öğretimi [Constructivist Learning and Geography Teaching]. Marmara Coğrafya Dergisi (Marmara Geography Journal), 1(10), 83-94,

Andrews, K. (2017). Culture, Curriculum, and Identity in Education. [Book Review]. Journal of Ethnic and Cultural Studies, 4(2), 99-101.

Asan, A., \& Güneş, G. (2000). Oluşturmacı Öğrenme Yaklaşımına Göre Hazırlanmış Örnek Bir Ünite Etkinliği [A Sample Unit Activity Based on Constructivist Learning Approach]. National Education Journal, 147, Ankara: MOE Publications.

Aslan, D., \& Aydin, H. (2013). Voices: Turkish students' perceptions regarding the role of supplementary courses on academic achievement. The Anthropologist, 16(3), 631643.

Aslan, D., \& Aydin, H. (2015). Evaluation of the teaching processes at science high schools based on a constructivist approach. A scale development study. Communications, 38(1A), 472-491.

Aslan, D., \& Aydin, H. (2016). Philosophical paradigms of constructivism: A review of literature. Usak University Journal of Educational Research, 2(2), 56-71.

Aydin, H. (2014). A comparative study between the United States and Turkey on teachers' lesson planning effort. Review of Research and Social Intervention, 46(1), 99-117.

Aydin, H., \& Aslan, D. (2016). Reliability and validity testing of a new scale for measuring attitudes toward pedagogical teacher training. Journal of Education and Learning, 5(3), 1-9.

Aydin, H., \& Cinkaya, M. (2018). Global citizenship education and diversity (GCEDS): A measure of students' attitudes related to social studies program in higher education. Journal of Multicultural Education, 12(3), 221-236. doi:10.1108/JME-05-2017-0030 
Aydin, H. (2019). The effect of multiple intelligence(s) on academic success: A systematic review and meta-analysis. EURASIA Journal of Mathematics. Science and Technology Education, 15(12), 1-22. doi:10.29333/ejmste/109008.

Büyüköztürk, Ş. (2012). Veri Analizi El Kitabı .(17. Basım). Ankara: PegemA Akademi Yayınları.

Colburn, A. (2000). Constructivism: Science education's grand unifying theory. Clearing House, 74(1), 9-12.

Dewey, J. (1939). Education and American culture. In Intelligence in the modern world, J. Ratner (ed.). New York, NY: New Library.

Driscoll, M.P. (2000). Psychology of learning for instruction. Boston, MA: Allyn \& Bacon.

Glasersfeld, E.V. (1998). Cognition, construction of knowledge, and teaching. In Constructivism in science education, M.R. Mathews (ed.), (pp. 11-30). Dordrecht: Springer.

Fer, S., \& Cirık, İ. (2007). Yapılandırmacı Öğrenme Kuramdan Uygulamaya. (Constructivist Learning: From Theory to Practice). İstanbul: Morpa.

Güneş, G ve, \& Baki, A. (2011). Dördüncü Sınıf Matematik Dersi Öğretim Programının Uygulanmasindan Yansimalar (Reflections from the Application of Fourth Grade Mathematics Course Curriculum). Hacettepe Üniversitesi Eğitim Fakültesi Dergisi, $41,192-205$.

Hall, N. \& Quinn, R. (2014). Parental Involvement at the High School Level: Parents' Perspectives. Journal of Ethnic and Cultural Studies, 1(1), 13-21.

Halpern, C. (2017). Book Review: In search of understanding: The case for constructivist classrooms. American Journal of Qualitative Research, 1(1), 32-36.

Huang, H.M., Rauch, U., \& Liaw, S.S. (2010). Investigating learners' attitudes toward virtual reality learning environments: Based on a constructivist approach. Computers \& Education, 55(3), 1171-1182.

Kalaycı, Ş. (2008). SPSS Uygulamalı Çok Değişkenli İstatistik Teknikleri. [SPSS Applied Multivariate Statistical Techniques]. Ankara: Asil.

Kaptan, F., \& Korkmaz, H. (2001). İlköğretimde Fen Bilgisi Eğitimi. Ankara: MEB. Yayınc1lı [Science Education in Primary Education]. Ankara: Ministry of Education. Publishing.

LaPaglia, K. (2018). Book Review: Critical pedagogy: Notes from the real world. American Journal of Qualitative Research, 2(2), 150-153.

Mahoney, M.J. (2004). What is constructivism and why is it growing? Contemporary Psychology, 49, 360-363.

Ministry of Education (MOE) (2005). Illkögretim1-5. Sinıf Programları Tanıtım El Kitabı [Primary education 1-5. Grade Curricula Introductory Handbook]. Ankara: State Books.

Ornstein, A. C., \& Hunkins, F. P. (2014). Foundations, principles and theory. Thousand Oaks, CA: Sage.

Özdamar, K. (1999). Paket Programlar Ile İstatistiksel Veri Analizi [Statistical Data Analysis with Packaged Software]. Eskişehir: Kaan.

Piaget, J. (1964). Development and learning. Readings on the development of children. In Piaget Rediscovered, R.E. Ripple \& V. N. Rockcastle (eds.). Ithaca, NY: W. H. Freeman and Company Press.

Sönmez, V. (2008). Öğretim İlke ve Yöntemleri (2. Bask1) [Teaching Principles and Methods (2nd ed.)]. Ankara: Anı Publishing.

Thanasoulas, D. (2002). History of English language teaching. Retrieved from https://bit. ly/2NHLz3n. 
Toraman, C., Aydin, H., \& Ulubey, O. (2016). Exploring teacher candidates' attitudes towards pedagogical teacher training based on different variables. International Education Studies, 9(9), 74-86.

Ulubey, O., Aydin, H., \& Toraman, C. (2017). Determining to which degree pedagogical teacher training serves the teaching profession: A scale development study. Transylvanian Review, 26(1), 55-74.

Vygotsky, L.S. (1997). Educational psychology. New York, NY: St. Luce Press.

Woofter, S. (2019). [Book Review]: Building equity: Policies and practices to empower all Learners. American Journal of Qualitative Research, 3(1), 136-139. https://doi. org/10.29333/ajqr/5815.

Yıldırım, A., \& Şimşek, H. (2008). Nitel Araştırma Yöntemleri (7. Baskı) [Qualitative Research Methods (7th ed.)]. Ankara: Seçkin Publishing. 